\title{
EDUCATION IN THE WORLD OUTLOOK DIMENSION: SHAPING FUTURE TEACHERS' SCIENTIFIC WORLDVIEW
}

\section{Maryna Kolesnyk ${ }^{1}$}

DOI: https://doi.org/10.30525/978-9934-588-53-2-16

Abstract. Fundamental transitions in worldviews, cultural patterns, as well as ecological, social and political upheavals determine re-addressing a number of issues concerning the nature and purpose of mankind as a species that acquire a new sense in this dynamic context. Current epistemic transformations witness a new vision of systems' development that becomes largely eco-oriented rather than technology centered. This article accentuates the natural orientation of social development as a promising vector of progress. Multidisciplinary paradigms in present-day science and education presuppose integration of diverse approaches towards the phenomenon of man and its interaction with nature in the sense of the causative-consecutive premises of systemic interactions. Axiological and teleological significance of natural sciences as well as integration of natural-scientific and humanitarian knowledge allow interpreting the image of the world as a wholesome scientific picture. This article aims at providing argumentation for the effectiveness of the causative-systemic approach towards identifying and describing the basic components of NSPW. Argumentation results from the multi-level systemic analysis of phenomena of diverse etiology and modeling their optimal development in accordance to the laws of nature. We speak of the integrative educational content modeled on the basis of the causative-systemic approach that reflects the algorithms of the universal laws of nature. The article addresses the issue of shaping a person's integral world outlook as premises of scientific worldview. The said objective is pursued via a number of methods and techniques designed on the basis of the causative-systemic approach and the algorithms suggested by the universal laws of nature. The paper

\footnotetext{
${ }^{1}$ Associate Professor at the Biology Chair,

T.G. Shevchenko National University «Chernihiv Collegium», Ukraine;

$\mathrm{PhD}$ in Education, Postgraduate Student,

Ternopil V. Hnatiuk National Pedagogical University, Ukraine
} 
considers a number of universal concepts that connect natural-scientific and humanitarian components of a worldview and approaches a student's development as a multi-factor process. The article discusses the theoretical background of the model of shaping universal scientific worldview the latter being responsible for pedagogical universities' students' responsible and integrative attitude towards nature. The paper considers methodology of implementing the said model within the structure of an experimental optional academic course and discusses the most relevant results of the experiment. The notion of «the image of the world» is treated off as a professional factor of a future teacher's educational activity. The article suggests a model of synthetic universal scientific picture of the world which encompasses synergistically correlating knowledge from the fields of physics, biology, chemistry as well as fundamental assumptions from humanitarian areas. The suggested model of shaping universal scientific worldview explicates basic «nuclear» clusters of methodological, naturalscientific and didactic nature. Potential implementation of the said model into the integrated content of education is expected to increase the level of future teachers' theoretical synthetic thinking. The article attempts to verify whether the current content of high school biological education complies with the fundamental laws of nature and analyses a number of concepts introduced in modern manuals in natural studies used at the university level of education. The paper highlights didactic principles of modeling picture of the world in regard to their correlation with the laws of nature. The article provides methodological argumentation for the stages of shaping naturalscientific worldview in regard to their correlation to the didactic conditions and methods. The article highlights the idea of conscious introduction and comprehension of the worldview-level notions during the learning process on the basis of the suggested model.

\section{Introducation}

Modern understanding of the world reflected in a number of worldviews including the scientific one is multi-dimensional. Present-day scientific worldview (SW) (synonymic to the «picture of the world» (PW), for we differentiate worldview as a conceptual interpretational filter and «picture of the world» as inferential experience) encompasses our knowledge of nonlinear processes, sustainable development, genetic code of matter employed 
in genetic engineering, synergetic patterns, cybernetics and biotechnology, insights in linguistics and cognitive science. A number of social issues and global challenges faced by humanity constitute the general context for the rise of the SPW. Modern science attempts dealing with unpredictable processes, paradoxes and chaotic phenomena. The idea of science itself as a linear and logical succession of research activities is currently transforming into the concept of a considerably irrational and non-predictable process.

Traditional SW encompasses the notions of matter, movement, space and time. Information has recently been added to that list while it has been acknowledged that information does manifest certain peculiarities pertaining to matter. Thus the phenomenon of information is tackled from the standpoint of physics, chemistry, biology, geology. Structural-systemic hierarchies of informational phenomena are then described as respective material systems. However, traditional methods in natural science and education appear to be ineffective while dealing with objects and phenomena of complex nature. Therefore complex objects are treated off as wholesome systems comprising the objects and their connections and relations. The suggested systemic approach towards interpreting and introducing natural phenomena in educational activities focuses on the search for universal and fundamental connections and relations between objects of diverse nature.

\section{Paradigmatic transformations of the present-day scientific worldview}

The essence of SW is treated off within the framework of the general theory of systems as well as the basic concepts of systems' self organization theory. As a system's self organization occurs while it acquires a spatial, temporal or functional structure without a specific outer impact [23, p. 28], we regard space, time and energy as fundamental relative parameters that could describe any system. Systems' temporal dynamics and the issues of man-nature relations are considered in terms of synergetic interactions $[16 ; 17]$. Thus, a human being as a subject of SW is not its focus per se. The creator and carrier of SPW is obligatorily identified as a hierarchical and synergistically active element of natural and social systems. Consequently, SPW provides systemic rationalization for human activities targeting the world, the latter being humans' fractal correlate. As complex systems are very sensitive to fluctuations, even weak ones can be amplified and impact 
the whole system. The ideas of universal relative parameters and minimal fluctuations' impact are employed in modeling the content of natural education as a systemic phenomenon.

Modern education requires developing human worldview that necessarily contains nature-relevant component. A positive life-oriented worldview and respective social lifestyle are identified as the primary objective of education [6]. Developing nature-oriented SPW that allows systemic interpretation of the multitude of challenges that the world provides requires re-considering the theoretic fundamental components of education. The Memorandum of the 1994 international UNESCO symposium accentuated the idea of education's fundamentals' orientation i.e. the focus of educational content on methodological invariant components of knowledge that stimulate initiation, realization and development of students' creativity. S. Honcharenko [4] identifies fundamental branches of science as those which operate the primary notions, concepts and laws, non-derivative from other epistemic areas. As physics, biology and chemistry are acknowledged as fundamental branches of science, the knowledge of the natural laws is expected to become the foundation of the educational content (and SPW in the long run).

\section{Interdisciplinary premises of shaping scientific worldview}

Education appears to be a wide-range socio-cultural, socio-economic and didactic phenomenon [3]. Therefore education becomes the focal sphere for natural science, social and technical science etc. This combination that marks modern natural scientific activities best addresses the universal natural phenomenon of cyclic development. Attempts of multi-disciplinary approach were made late in the XX A.D. For instance, the introduction of the term «systemic-activity approach» in 1985 was supposed to negate the contradiction in psychological research between the «systemic approach» [1] and «activity oriented approach» [9].

We highlight the existence of the wholesome natural-scientific worldview within the structure of a general SPW that results from incorporating all liferelated data provided by diverse branches of natural science $[5 ; 7 ; 18 ; 19 ; 22]$. Therefore we speak of developing students' natural-scientific worldview or picture of the world (NSPW) as a personal experience of reality mediated by social knowledge and experience of Nature. We believe that splitting a 
wholesome NSPW into discrete physical, biological or chemical SWs serves no purpose and therefore is incorrect. The wholesome NSPW is regarded as the result of emergent systemic development, where the final properties of a system exceed the mere combination of its subsystems' features.

Our primary objective is the search for effective approaches and means of shaping students' wholesome NSPW either by generalizing and systematizing fundamental laws, theories, notions and principles of particulate «field» SWs into an integrated NSPW or by consecutive introducing certain volume of knowledge and interpreting it through the prism of universal laws of nature while teaching specific topics in class $[4 ; 6 ; 19 ; 20 ; 21 ; 22]$.

Fundamentals of continuous shaping the knowledge of natural laws in accordance to pupil's age peculiarities are introduced in [6] where the idea of «continuous onto-didactic axis» is discussed. M. Sydorovych [21] argues for the methodological effectiveness of splitting the NSPW into three local ones (biological, physical and chemical) while introducing the knowledge of the living matter which is, as we have pointed out, not entirely systemic. However, the focus on individual peculiarities of future teachers as carriers and transmitters of NSPW is definitely promising.

\section{Causative-systemic approach towards modeling scientific worldview}

Recent scientific developments and the focus on formerly inaccessible objects of research correlate with the rise of new values and worldview orientations. Thus we speak of the emergence of the new scientific paradigm which demonstrates the tendency towards multidisciplinary analysis and universalia orientation. Multidisciplinary causative-systemic approach complements the basic assumptions of synergetic studies and allows stepping away from treating off self-organization as an indeterminate process and identifying it as systems' qualitative transformation determined by universal natural laws. Reconsidering and highlighting these universalia has actually shaped causative systemology and causative-systemic analysis as a research methodology $[13 ; 14 ; 15]$. Universalia-oriented scientific paradigm tackles phenomena of life in regard to universal patterns of development which determine systems' structural reiteration in time and space dimensions at micro and macro levels. 
Modern philosophic premises of NSPW stimulate systemic interpretation of this phenomenon rather than descriptions of its components. For instance, Lojfman I'.Ya. [8] advocates wholesome perception of general and natural-scientific issues to avoid their one-sided interpretation. Thus, systemic approach towards NSPW presupposes the simultaneous analysis of respective objects in ontological, gnoseological and methodological aspects [24].

\section{Methodology}

The objectives of our research determine its logic and sequence of stages: observing the subject under conditions of university education, analysis of the current methodology in the theory of education potentially applicable to the issue under analysis, creating a hypothesis i.e. a model of universalia-oriented NSPW.

The said model is further utilized for analyzing the content and structure of natural scientific academic courses at the bachelor level educational programs. The model is also implemented for modeling optional courses in the same area of education.

A number of the following methods were used to achieve the objectives: functional and structural analysis, historical analysis of educational modeling, synthesis of didactic, philosophic, sociological, psychological, biological theoretical premises of SW and the process of its development, comparison and generalization of the data obtained from analyzing curricula of the natural-scientific academic subjects, specification of the elements included into the modeled process of developing NSF.

\section{The universalia-oriented scientific worldview in the content of natural-scientific education}

We identify the universalia-oriented NSPW as organized, integrated and conceptualized knowledge of the world (a wholesome image of the world and the multitude of states of affairs in it) obtained from the data and experience provided by a wide range of scientific fields and interpreted via the filters of the universal laws of nature. We implement causativesystemic approach towards its modeling. Its causative aspect is defined by the universal triple-like hierarchic correlation between phenomena that appears as [subsystem - system - over-system] pattern (i.e. [cell - 
organism - biosphere]) in which the over-system provides purpose of the triad's lower components and determines their functions and the vector of development. The systemic aspect presupposes the focus on peculiarities of systems/static structure, dynamic developments, meta-systematic adaptations, predicting their possible trajectories of development as well as reconstruction of specific connections between systems at different levels of matter's organization. This approach allows:

- Structuring information thus facilitating orientation in dense informational spaces;

- Acquiring information via causative-systemic algorithm (connectioncentered informational search);

- Specifying the properties of the objects under study and the areas of analysis;

- Demonstrating the dynamics of the object's development;

- Adapting the object to larger systems;

- predicting the ways of the object's development in realtime;

- modeling an ideal object and the most effective patterns of its development.

We identify seven causatively connected levels of the Man - World relations which correspond to the seven basic levels of the living matter's organization. Each level represents different modes of a culturally creative personality's integrated experience. The said levels are labeled as: psychophysical(1), psycho-emotional (2), mental (3), social-adaptive (4), collectively interactional (5), social-axiological (6), integrative-conceptual (7).

The logic of identifying these seven levels of systemic organization is further applied to the didactic principles, each targeting respective human faculties:

1. The principle of individual approach (i.e. considering individual physiological peculiarities, motor and manual functions)

2. The principle of psycho-emotional relevance (i.e. setting and maintaining positive emotional environment favorable for learning).

5. The principle of science-orientation and accessibility of knowledge (i.e. considering students' intellectual capacity and skills of carrying out mental operations)

4. The principle of continuity and practical congruity (i.e. addressing everyday experience in continual learning and applying it to real life issues) 
5. The principle of integration (i.e. using group experience in learning, interaction and cooperation in learning).

6. The principle of consistency (i.e. learning along the guidelines of a system of values).

7. The principle of integrity and purpose (i.e. targeting the development of a worldview based on the integral understanding of life and natural patterns of existence).

These principles correlate with the laws of nature and general patterns of systems' functioning. We address the said patterns as simultaneous multi-leveled structuring of matter in the known Universe i.e. generating spatial structures and their diachronic development as multidimensional hierarchies, micro- and macro-worlds. The laws of Nature are regarded as universal «navigational guidelines» for these developments, while their conscious implementation in shaping the worldview pursues effective prognosis of living systems' sustainability. The worldview focused on the living systems (or the system of Life) encompasses the knowledge of hierarchically structured experience acquired by these systems in cyclic, causative and purposeful development (the purpose being predetermined by larger systems and general laws while not necessarily comprehended in micro-contexts).

Except for the general laws of Nature, the methodology of shaping NSPW highlights the systems' capacity for self-organization. The notion of self-organization is widely used yet differently interpreted in natural science and humanitarian areas of knowledge. In our paper we regard self-organization as a system's inherent ability to modify and improve its structure in diverse contexts. As all natural systems are fundamentally capable of self-organization (virtually free from «human assistance») the understanding of this fact is expected to shape the focal concept of natural education as well as the process of shaping NSPW. Present-day theory of education gradually transgresses towards the concept of education's natural-scientific component being a configuring factor of understanding Life and developing respective worldview. Thus we operate concepts like «biospheric optimism», «biospheric education», «automatic biosphere» etc. However the global challenges that we face these days stimulate our going further than these concepts. Therefore, shaping NSPW aims at generating a wholesome image of a sustainable world in which Nature is the ultimate 
value (in other words, this image is treated off as a complex mental entity encompassing a wide range of causative relations between components of diverse etiology). In this case, the focus on systems' emergent properties (cf. Vernadsky's thesis [2] that denies considering any living object outside the sphere of life) opens up an entirely new level of understanding of Life.

The focus on universal laws of Nature is hence the key component of both creating the NSPW and modeling the educational process. As the world moves on struggling through a number of dramatic issues, presentday education is expected to provide modern knowledge, develop up-todate skills and competences via modern educational programs. Therefore each educational subject at the level of higher education is expected to contribute to shaping the students' NSPW by providing adequate contents and curricula's structure (Figure 1).

A system's development unfolds through twelve stages at each of seven possible organizational levels. Successful learning at each stage demands

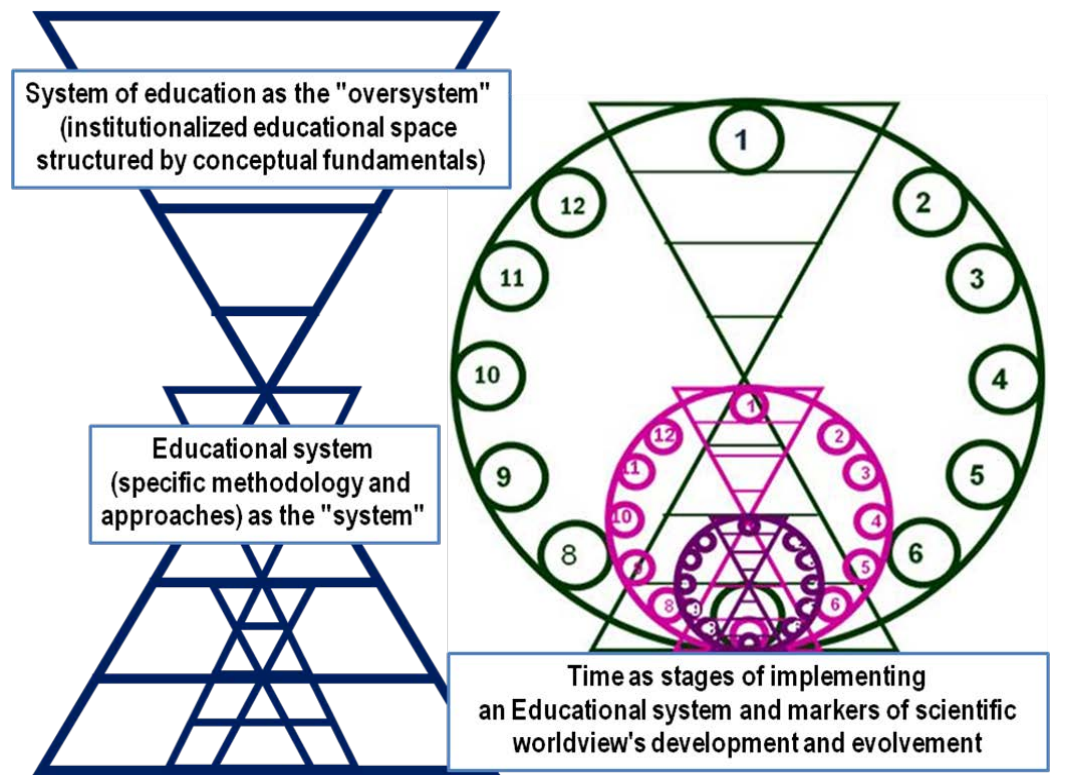

Figure. 1. Static (spatial) and dynamic (temporal) dimensions of educational system 
«synchronized» education. The latter is identified not only as regular rhythmic educational activities but rather as a determined correlation of diverse educational processes (Figure 2). In this context we speak of the system's coherence i.e. its subsystems' correlative, purposeful and coordinated functioning. A coherent dynamic system develops emergent faculties that are absent in its discrete components.

Asynchronized wholesome educational system provides each personality with an individual trajectory and speed of experience acquisition while maintaining general conceptual premises of development. The mechanism of synchronization involves resonance. As a universal physical phenomenon, resonance is tackled in curricula of natural academic subjects as well as in social sciences. Normally resonance can trigger both adaptation of flexible systems to new environment, generation of new systems or destruction of rigid ones. A system of educational nature coordinates its elements (causes them to resonate) by means of adjusting its basic parameters by a number of managing activities. Resonance in educational modeling corresponds to dialectic patterns of evolution. For instance, quantitative transformations in the educational content eventually result into restructuring programs and curricula and potentially found an entirely new system (Figure 3 ).

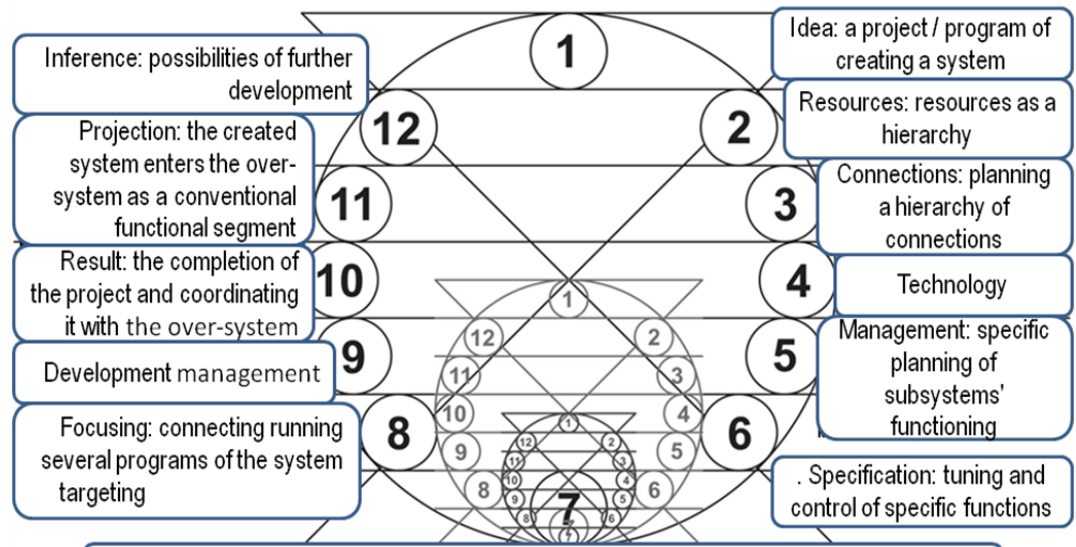

Systematizing: assembling a coordinated "functional nod"

Figure 2. Synchronizing development cycles in the nature-oriented educational system 
Continuous generation and decomposition of organic structures occurring at the organism level demonstrate the essence of metabolism (according to one of the concepts, metabolism is the primary process characterizing life). This phenomenon is responsible for maintaining the organism's structure under different and changing outer conditions. Organism's structural integrity manifests itself as dynamics rather than stasis. However, all processes, their combinations and sequences pursue the goal of maintaining the system's comfortable state i.e. anti-entropy mode in terms of energy balance, informational and structural integrity.

Thus we regard universal NSPW as a sustainable systemic mental construal resulting from interdisciplinary interpretations and encompassing present-day knowledge from separate areas of science correlating with biological, physical, chemical and mathematical worldviews. It is organized according to general philosophic principles therefore it can be modeled as a sequence of relatively simultaneous operations directed towards organizing a «conceptual space» containing diachronically acquired human experience of life and living matter. The natural-scientific branch of NSPW is complemented by the humanitarian one that provides contexts for natural experience's social application.

The causative-systemic approach towards modeling NSPW considers activities as a focal component of education allowing students to acquire knowledge and experience as well as develop the understanding of causativeconsecutive relations between phenomena while engaged in analytical and synthetic learning procedures. The said relations are addressed as both synergetic and natural. The synergetic core of the suggested methodology is complemented by specific techniques which demonstrate the mechanisms of social and natural objects' auto-organization and sustainability thus targeting a number of universal concepts as premises of systemic NSPW.

We regard causative-systemic worldview and the premises of NSPW and identify the former as a dynamic set of views, beliefs, estimations and images of the world structured hierarchically and synergistically according to fundamental laws of nature. These components of the worldview determine the way the input information is perceived, interpreted and categorized and also define strategies and tactics of social interaction at different institutional levels. We speak of «causative-systemic world view» and «scientific world view» as synonyms. On the other hand, we 
Humanitarian branch Synthetic universal scientific worldview Natural-scientific branch

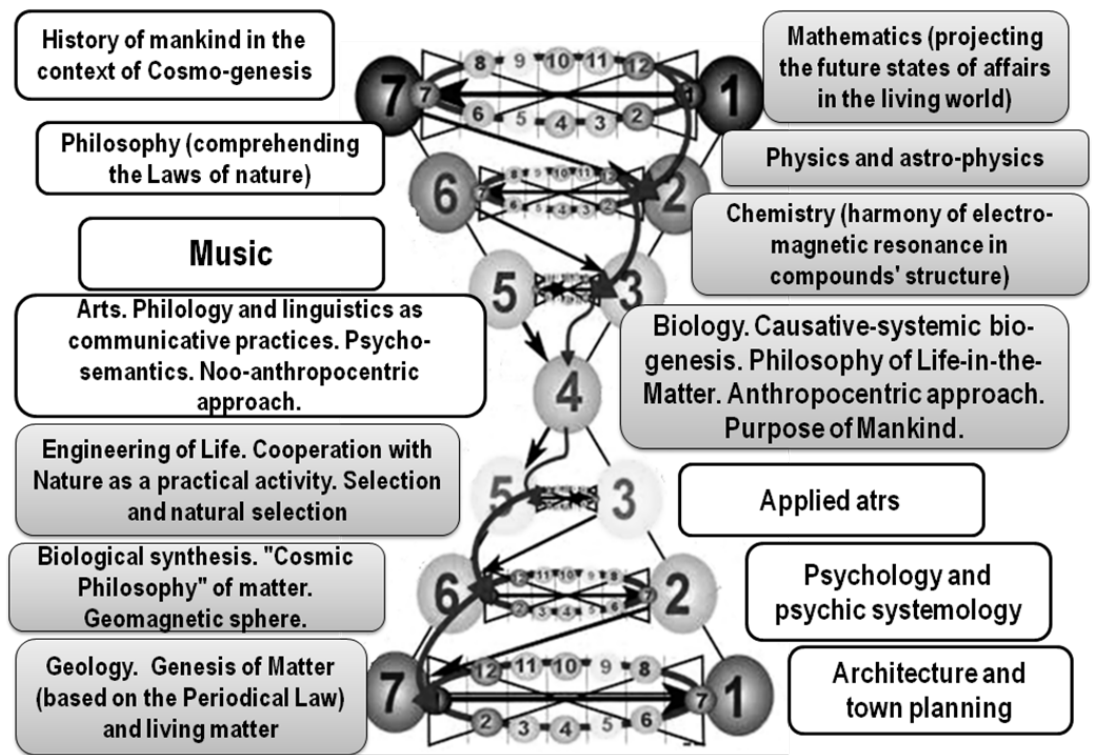

Figure 3. The model of synthetic universal natural scientific worldview (1-7 natural-scientific branch; 7-1-humanitarian branch)

differentiate the notions of «the image of the world», «scientific picture of the world» and «scientific worldview».

Construing a NSPW depends on a number of mental functions, primarily those responsible for inferential knowledge and dialectic analysis that revels causative relations between phenomena and processes as they emerge and re-occur at different levels of existence. NSPW also encompasses philosophic values and estimations, relations, beliefs and images which ascribe certain worldview-like features to the subject-matter knowledge of the world.

\section{Shaping scientific worldview as a part of education}

It is the formation of NSPW that present-day education ought to provide. The stereotypic belief that higher education provides a complete skill-set for effective professional activity and development is no longer valid. The new concept of continuous education focuses on the person's worldview. 
Scientific worldview is indeed structured around fundamental and specific concepts and ideas necessary for professional activity although specific professional training at the level of higher education appears to be limited in its relation to the scientific worldview [11]. We state that fundamental academic subjects are capable of contributing to the new quality of education i.e. providing both professional skills, shaping a worldview, facilitating person's auto-identification in the world, self realization in the cultural framesets.

Among the number of scientific worldview's components currently discussed are human world perception, world understanding and world modeling. Except for the informational plane (knowledge and skills), modern scientific worldview concerns human creativity (mostly addressed in humanitarian subjects). Therefore natural scientific and humanitarian spheres of education are expected to collectively define and provide mental navigational guidelines for creating NSPW.

Thus we regard worldview as a tool of shaping NSPW and speak of the necessary integration of respective educational branches and subjects. This synthetic methodology of education targets the ability of tackling the multitude of worldly phenomena from diverse perspectives, and allows seeing the reasons and patterns of their development. Hence we treat off NSPW as an integral cognitive image of the world in which pure knowledge of natural phenomena becomes axiological thus defining relevant senses and purpose of human existence (i.e. contributing to upbringing that goes along with education).

Apart from being a mental model that facilitates further interpretation of existential phenomena, NSPW implies their causative nature and employs universal cultural (noospheric) values. NSPW is therefore a product of scientific and educational paradigms' synthesis.

NSPW is structured as a multidimensional space, a projection of the future expected (desired) states of affairs based on the prior experience and encompassing the image of mankind, the image of society, the image of a group, the image of a human being, the image of activity, the image of relations, the image of life (Figure 4). Both NSPW and its subject (the cultural-creative personality) function according to the laws of nature therefore we draw analogies between their structure and the hierarchies of living systems. 
Attempts have recently been made $[10,12]$ to integrate basic concepts of philosophy, medicine and theory of education to explain the nature of man. This integrated anthropological approach considers human worldview as a system of knowledge, views, estimations and images that are actively generated rather than passively acquired. Consequently we regard causativesystemic worldview as a cognitive-interpretative tool that provides natureoriented and axiologically colored inferential knowledge thus generating the above mentioned images and NSPW in general.

Causative-systemic worldview allows combining rational and irrational interpretational procedures thus providing multi-aspectual analysis of respective objects, phenomena and processes. The said integration becomes possible via addressing phenomena from the standpoint of diverse academic subjects through the prism of universal laws of nature (Figure 5).

Successful modeling of NSPW relies on a number of factors:

- bio- / eco-centric worldview that also encompasses fundamental cultural values thus providing holistic understanding of the Life phenomenon and prognostic vision of human activities' possible negative impacts;

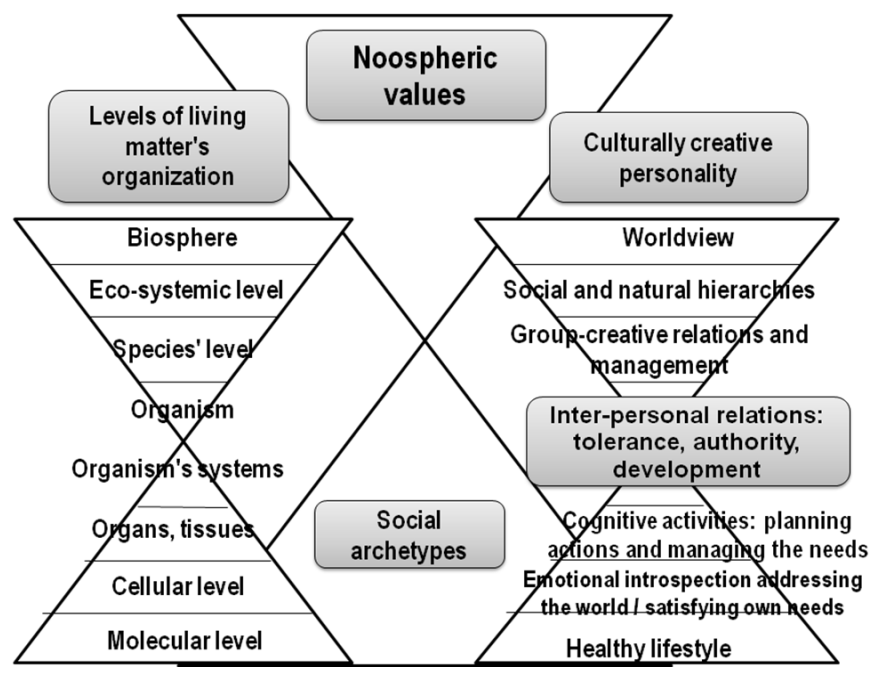

Figure 4. Axiologial guidelines of a culturally-creative personality as a subject of natural-scientific picture of the world 

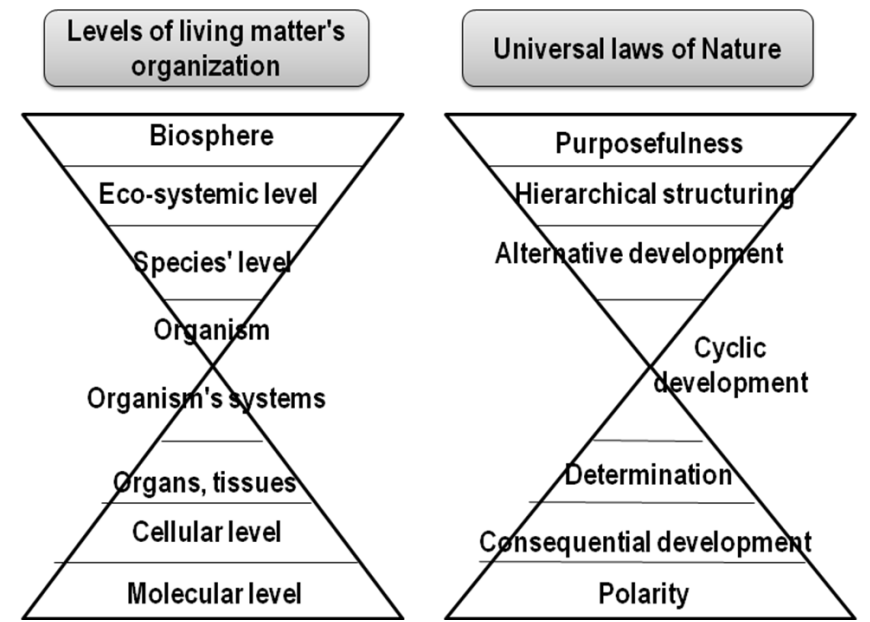

Figure 5. Correlation of laws of nature and the hierarchies of living systems

- personal involvement in social relations and the ability to exercise one's skill set and experience in social practices;

- introducing the basics of strategic planning and team work while solving locally relevant ecological issues;

- balancing individual and social values and preferences;

- integrated multi-disciplinary knowledge about the environment; engaging in activities for environmental protection;

- seeing the beauty of Nature;

- responsible treatment of environment and health.

At this point let us identify the crucial systemic factor relevant for shaping NSPW. According to P. Anohin, insufficient (unsatisfactory) result of a certain process might impact the choice and integration of the respective re-occurring scenario's participants (components) so that the further result should become positive. We regard this phenomenon of system's mutual coherent reinforcement as the basic system-shaping factor. Hence we extrapolate this thesis onto the educational activities aiming at shaping NSPW. In this case participants of educational activities do not simply interact but rather cooperate and pursue certain useful achievements. 
However, there is yet another systemic factor which provides real sense to the former one. We speak of the vector of effective development of living systems' hierarchies that defines their gradual formation, structuring and synchronization. This factor, correlating to causative-systemic laws of nature, is applied to the fundamental goals of natural and universal education:

1.Worldview goals. Forming holistic causative-systemic worldview that provides fundamental understanding of natural processes and identifying oneself with the world as its integral part thus stimulating the balance between individual, social and natural incentives in human pragmatics. As a result, it is natural for a person to consider personal, social and human goals as equally important.

2.Axiological goals. Forming stable evolutionary values allows seeing the purpose and sense of life and re-focusing from individual issues towards evolution-relevant ones.

3. Social goals. Facilitating collective strategies and collective evolutionary creativity at different stages of educational process aims at development of the new type of leadership and creativity.

4.Intra-personal and social-adaptive goals. Forming a person's responsible and active social position stimulates the understanding of one's affiliation and inclusion in the states of affairs, responsibility for evolutionary changes and consistency in pursuing the objectives.

5.Informational goals targeting the development of creative thinking and skills of information filtering and processing.

6. Ethical goals of acquiring the experience of effective relations that reflect the universal patterns of systemic interactions.

7.Health care goals. Providing incentives for healthy life style, realizing the connection between the lifestyle and organism's physiological conditions.

Achieving the above mentioned goals is possible on the conceptual basis of the universal scientific worldview of the subjects involved in educational activities, i.e.:

1. Considering any pedagogical phenomenon (virtually any phenomenon) follows the logic of tackling it as a system (complex system) which is a part of a larger macro-structure which defines the rules and patterns of its functioning. 
2. Any system attempting to identify its own purpose interacts with equi-ranking thus entering a bigger system and acquiring new systemic qualities..

3. A hierarchically structured system is characterized by multi-valence that provides it with a variety of development trajectories. Systemic interactions manifest certain duality in terms of a system's functioning as a cluster of its components as well as a system's interacting with a larger one in the capacity of the latter's component.

4. Emergence and development of a pedagogical system are determined by inter-systemic, psycho-systemic and intra-systemic connections and interactions.

5. Any system (complex system) is a multi-level hierarchy. Its components fulfill three fundamental functions: regulation, communication, and cognition.

6. Any evolving open system enters the stages of differentiation and integration.

7. Any evolving open system goes through transitions which result into its reaching qualitatively new levels of organization.

8. Psycho-systemic analysis and psycho-systemic modeling are the tools that both highlight pedagogical system's universal structure and facilitate shaping universal NSPW.

Therefore a teacher's primary objective ought to be revealing to the students the purpose of existence in regard to the universal laws of nature. Consequently, future teachers (students majoring in natural science and education) ought to be provided with this fundamental concept. Pursuing of this goal stimulates a certain tension between teachers and students (polarity as the premises of development); the transferring of the idea of nature-oriented development acquires the quality of a cultural concept; the graduates majoring in natural sciences and education are expected to manifest a wider worldview (based on the expanded consciousness capable of comprehending causality of all phenomena in the world); eventually, the formation of NSPW ought to be a gradual consistent process of students' acquiring proper experience and developing the ability of making conscious choices in the context of nature-oriented systemic interactions.

The said primary objective requires a fundamental expansion of current methodology and conceptual premises. Most of models of human 
development employed in present-day theory of education do not reach higher than the professional or social levels (cf. Maslow's «hierarchy of needs» or Bloom's taxonomy) i.e. are devoid of reflecting universal axiology and fundamentals of world's organization. Thus these educational models deprive people of understanding the reasons and purposes of social and professional development, limit their vision of the world (and mental development in terms of inability of volumetric causative analysis) and progressive inter-systemic interactions.

The primary factors that stimulate the rise of the universalia-oriented approach in education and forming NSPW are:

- dominant approaches towards fundamental knowledge as a part of the content of education;

- primary principles exercised in shaping NSPW;

- specific criteria implemented for choosing the content of education (worldview orientation);

- primary resources as intra-subject, cross-subject and trans-subject connections and correlations employed for forming the knowledge of universal patterns of systems' development.

Therefore we suggest to expand the notion of «content of education» by extending current models to the level of axiological interpretation (respective components of the content of education are interpreted via the scope of universal values and arranged according to general epistemic maxims of systems' functioning) and the level of teleological interpretation (components of the content of education are tackled via the scope of projected purposes and expected transformations in the states of affairs).

\section{Conclusions}

Designing a model of NSPW and the ways of its shaping require generalizations at methodological, philosophic, general scientific and specific scientific levels.

Present-day tendencies of inter-epistemic integration correlate with the suggested approach towards modeling the content of education primarily its natural-scientific component aiming at the formation of NSPW. Universal integrated NSPW is shaped on the basis of general gnoseological maxims and the principles of causality, hierarchical structuring, mutual determination and self-organization of systems involved in micro- and 
macro-processes. Respective mental modeling as the algorithmic projection of nature-oriented states of affairs organized as «the image of the world» unfolds according to the general laws of nature. The said algorithm is a part of the suggested causative-systemic approach towards education. Each of the natural laws under discussion correlates with the maxims of dialectics. The latter are explicated via the analogies with the functioning of natural objects and natural phenomena. These analogies are implemented for modeling a general NSPW, including its natural-scientific and socialhumanitarian segments. Modeling a NSPW and its qualities depend on the subject's worldview hence we speak of certain analogies between NSPW's shaping and one's worldview's formation.

Thus we argue for the following fundamental methodological assumptions of modeling a universal NSPW.

1. Hierarchical arrangement of NSPW's functional constituents corresponds with the levels of living matter's organization.

2.Causative-systemic approach towards modeling NSPW is centered around the notion of causative-systemic worldview, the latter being an experientially obtained dynamic causatively-consecutively structured system of ideas, estimations and images of the world correlating to the general laws of nature and functioning as a tool for further perception, interpretation and categorization of the world and a determiner of strategies and tactics in inter-human and social (educational as well) interactions.

3. Basic notions constituting NSPW (primarily in the context of naturalscientific education) are explicated via an integrated approach to natural phenomena that defines their theoretical, methodological and applied significance.

4. Multi-level systemic thinking is treated off as an epistemic tool involved in education and employed in modeling NSPW.

5. Continuity of education is revealed in its complementation to one's worldview and is largely responsible for shaping a relevant up-to-date NSPW.

\section{References:}

1. Ananyev, B. G. (1974). K psikhofiziologii studencheskogo vozrasta. Sovremennye psikhologo-pedagogicheskie problemy vysshey shkoly [On Physiology of Students' Age. Modern Psychological-Pedagogical Issues of Higher Education]. Leningrad: Leningrad University Press. (in Russian) 
2. Vernadskij, V. I. (1967). Biosfera: izbrannye trudy po biogeokhimii [Biosphere: Selected Works on Biogeochemistry]. Moscow: Mysl. (in Russian)

3. Gershunskij, B. S. (1998). Filosofiya obrazovaniya: Uchebnoe posobie dlya studentov vysshikh $i$ srednikh pedagogicheskikh uchebnykh zavedeniy [Philosophy of Education: A Manual for Students of Pedagogical Establishments]. Moscow: Moscow Psychological-Sociological Institute. (in Russian)

4. Goncharenko, S. U. (2013). Formuvannja u doroslykh suchasnoji naukovoji kartyny svitu: monoghrafija [Shaping Adults' modern Scientific Worldview]. Kyiv. (in Ukrainian)

5. Grubinko, V. V. (2015). Biosocialjna evoljucija ljudyny, seredovyshhe $i$ stalyj rozvytok [Biosocial Evolution of Man, Environment and Sustainable Development]. Ternopil: Ternopil National Pedagogical University Press. (in Ukrainian)

6. Ilchenko, V. R., Guz, K. Zh., \& Ilchenko, O. G. (Eds.). (2017). Teoretychni ta metodychni zasady integhraciji pryrodnycho-naukovoji osvity osnovnoji shkoly [Theoretical and Methodological Premises of Integral Natural-Scientific School Education]. Kyiv: «Sam» Publishers. (in Ukrainian)

7. Koreneva, I. M. (2018). Koncepcija pidghotovky majbutnikh vchyteliv biologhiji do realizaciji funkcij osvity dlja stalogho rozvytku [The Concept of Training Future Biology Teachers For IMplementing Educational Functions For Sustainable Development]. Bulletin of Kherson State University. Education, vol. 82(2), pp. 148-153.

8. Lojfman, I. Ya. (2000). Dukh dialektiki (teoretiko-metodologicheskie problemy) [The spirit of dialectics (theoretical-methodological issues)]. The Institute of Retraining Teachers of Humanities. Ekateringurg: UrGU. (in Russian)

9. Luriya, A. R. (2003). Osnovy neyropsikhologii. Ucheb. posobie dlya stud. vyssh. ucheb. zavedeniy [Fundamentals of Neuro-psychology: A Mannual for University Students]. Moscow: “Akademija” Publishing Centre. (in Russian)

10. Makacz, D. V., \& Makacz, V. G. (2004). Funkcionaljno-energhetychna systema ljudyny jak biofizychna realjnistj [Functional-Energetic System of Man as a Biophysical Fact]. Cultures of Black Sea Area Peoples, vol. 2, no. 56, pp. 188-192.

11. Martishina, N. I. (1998). Nauchnoe mirovozzrenie i obrazovanie [Scientific Worldview and Education]. Omsk Scientific Bulletin, vol. 3, pp. 4-5. Retrieved from: https://cyberleninka.ru/article/v/nauchnoe-mirovozzrenie-i-obrazovanie (accessed 12.05.2020).

12. Pidlasij, I. P. (2004). Praktychna pedaghoghika abo try tekhnologhiji. Integhrovanyj pidruchnyk dlja pedaghoghiv rynkovoji systemy osvity [Practical Pedagogic or the Three Technologies. An Integrated manual for Market Education Teachers]. Kyiv: "Slovo" Publishers. (in Ukrainian)

13. Polyakov, V. A. (1998). Gnoseologicheskiy relyativizm kak metod nauchnogo poznaniya [Gnoseological Relativity as a Method of Scientific Research]. Moscow: New Centre. (in Russian)

14. Polyakov, V. A. (1999). Gnoseologiya relyativizma i teoriya otnositel'nosti soznaniya [Gnoseology of Relativity and the Theory of the Relativity of Mind]. Moscow: New Centre. (in Russian)

15. Polyakov, V. A. (1996). Teoriya Otnositel'nosti Soznaniya [Theory of the Relativity of Mind]. Minsk: Vever. (in Russian) 
16. Prigogine, I. R. (1985). Ot sushchestvuyushchego $k$ voznikayushchemu [From Being to Becoming]. Moscow: Nauka. (in Russian)

17. Prigogine, I. R., \& Stengers, I. (2000). Poryadok iz khaosa. Novyy dialog cheloveka s prirodoy [Order out of Chaos: Man's new dialogue with nature]. Moscow: Editorial URSS. (in Russian)

18. Rudishin, S. D. (2009). Biologhichna pidghotovka majbutnikh ekologhiv: teorija i praktyka: monoghraf. [Training Future Ecology Experts in Biology: theory and practice]. Vinnytsia: "Tempus". (in Ukrainian)

19. Rudishin, S. D. (2013). Modelj naukovoji kartyny svitu [A Model of Scientific Worldview]. Modern School Biology and Chemistry, no. 3, pp. 2-6.

20. Sidorovich, M. (2016). Fundamentalizacija zmistu shkiljnoji biologhichnoji osvity [Providing Fundamental Premises for School Biology Education]. Biology and Chemistry in the Native School, no. 6, pp. 28-30.

21. Sidorovich, M. (2010). Naukovo-metodychni zasady formuvannja teoretychnykh znanj $z$ biologhiji $v$ uchniv zaghaljnoosvitnjoji shkoly [SChientificmethodological premises of developing secoindary school pupils' knowledge in biology]: Thesis for the Doctor's Degree in Education. 13.00.02 «Theory and Methodology of Teaching (Biology)». Kyiv. (in Ukrainian)

22. Stepanyuk, A., Grubinko, V., \& Kolesnyk, M. (2019). Innovacijni pidxody do formuvannya zmistu pryrodnychoyi osvity shkolyariv [Innovative approaches towards modeling the content of schoolchildren's natural education]. Osvita XXI stolittya: teoriya, praktyka, perspektyvy, materialy Pershoyi mizhnarodnoyi naukovo-praktychnoyi Internet-konferenciyi [Education 21 AD: theory, practice and perspectives]. Kyiv. (in Ukrainian)

23. Haken, H. (1991). Informatsiya i samoorganizatsiya: Makroskopicheskiy podkhod k slozhnym sistemam [Information and self organization: A Macroscopic Approach to Complex Systems]. Moscow: Mir. (in Russian)

24. Shutaleva, A. V. (2018). Filosofskie problemy estestvoznaniya: ucheb.posobie dlya bakalavriata i magistratury [Philosophical Issues of Natural Science: A Manual]. Moscow: Jurait Publishers. (in Russian) 